\title{
Comparison of Particulate Mercury Measured with Manual and Automated Methods
}

\author{
Robert Talbot ${ }^{1}{ }^{*}$, Huiting Mao ${ }^{1}$, Dara Feddersen ${ }^{1,2}$, Melissa Smith ${ }^{3}$, Su Youn Kim ${ }^{1}$, \\ Barkley Sive $^{1}$, Karl Haase ${ }^{1,2}$, Jesse Ambrose ${ }^{1}$, Yong Zhou ${ }^{1}$ and Rachel Russo ${ }^{1}$
}

1 Climate Change Research Center, Institute for the Study of Earth, Oceans, and Space, University of New Hampshire, Durham, NH 03824, USA; E-Mails: hmao@gust.sr.unh.edu (H.M.); dmy49@cisunix.unh.edu (D.F.); sk@gust.sr.unh.edu (S.Y.K.); bcs@ gust.sr.unh.edu (B.S.); khaase@gust.sr.unh.edu (K.H.); jambrose@ cisunix.unh.edu (J.A.); yzhou@gust.sr.unh.edu (R.Z.); rrusso@gust.sr.unh.edu (R.R.)

2 Department of Chemistry, University of New Hampshire, Durham, NH 03824, USA

3 Department of Earth Science, University of New Hampshire, Durham, NH 03824, USA; E-Mail: htimsyssim@gmail.com

* Author to whom correspondence should be addressed; E-Mail: robert.talbot@unh.edu; Tel.: +1-603-862-1546; Fax: +1-603-862-2124.

Received: 2 December 2010; in revised form: 30 December 2010 / Accepted: 15 January 2011 / Published: 20 January 2011

Abstract: A study was conducted to compare measuring particulate mercury $\left(\mathrm{Hg}^{\mathrm{P}}\right)$ with the manual filter method and the automated Tekran system. Simultaneous measurements were conducted with the Tekran and Teflon filter methodologies in the marine and coastal continental atmospheres. Overall, the filter $\mathrm{Hg}^{\mathrm{P}}$ values were on the average $21 \%$ higher than the Tekran $\mathrm{Hg}^{\mathrm{P}}$, and $>85 \%$ of the data were outside of $\pm 25 \%$ region surrounding the 1:1 line. In some cases the filter values were as much as 3 -fold greater, with $<5 \%$ of the points falling on the 1:1 line. A common characteristic in all seasons was that the Tekran only yielded a total of 6 data points above 1 part per quadrillion by volume (ppqv) (i.e., $\sim 4 \%$ of the observations), and had $\sim 25 \%$ of its measurements as below the limit of detection $\left(<0.1-0.2\right.$ ppqv). In comparison, the filter always had $\mathrm{Hg}^{\mathrm{P}}$ detectable above the blank level of 0.05 ppqv. The aerosol size distribution of $\mathrm{Hg}^{\mathrm{P}}$ did not appear to be a major factor in the discrepancies between the two methods. The peaks in filter $\mathrm{Hg}^{\mathrm{P}}$ were always concomitant with enhanced mixing ratios of selected hydrocarbons, halocarbons, and oxygenated compounds. Backward trajectories suggested that the peaks in all chemical 
compounds were primarily anthropogenic, and tracers indicated a combustion signature. Since the Tekran was typically unresponsive to these pollution episodes, detailed investigation of aerosol passing efficiency and the instrument response to different aerosol types should be investigated.

Keywords: mercury; particulate; filter; Tekran 1135

\section{Introduction}

Accurate measurements of mercury chemical speciation are required to understand correctly its cycling and lifetime in the atmosphere. In the atmosphere mercury exists in diverse chemical forms that are comprised of gaseous elemental mercury $\left(\mathrm{Hg}^{0}\right)$, reactive gaseous mercury $\left(\mathrm{RGM}=\mathrm{HgCl}_{2}+\right.$ $\left.\mathrm{HgBr}_{2}+\mathrm{HgOBr}+\ldots\right)$, and particulate-phase mercury $\left(\mathrm{Hg}^{\mathrm{P}}\right)$. Compared to $\mathrm{Hg}^{\circ}$ and $\mathrm{RGM}, \mathrm{Hg}^{\mathrm{P}}$ has received relatively little attention. Measurement of $\mathrm{Hg}^{\mathrm{P}}$ requires either sampling with filters [1,2] or application of an automated Tekran model 1135 in conjunction with the Tekran model 2537 cold vapor fluorescence detection system [3-5]. The Tekran system is commonly employed to determine speciated atmospheric mercury world-wide.

The filter method could be prone to both positive and negative artifacts such as adsorption of RGM onto collected particulates [6] or loss of mercury from collected particulates when sampling times of more than a few hours are employed [7]. The Tekran system may have artifacts related to phase partitioning that varies with temperature [8]. An intercomparison conducted at Mace Head, Ireland, showed that $\mathrm{Hg}^{\mathrm{P}}$ measured by participating groups was highly variable and at times different by nearly an order of magnitude [9]. Together, this limited work on $\mathrm{Hg}^{\mathrm{P}}$ suggests that current methodologies for $\mathrm{Hg}^{\mathrm{P}}$ measurements need to be investigated rigorously.

Measurements of $\mathrm{Hg}^{\mathrm{P}}$ in southern Québec, Canada, yielded an average concentration of $26 \pm 54$ picograms $(\mathrm{pg}) \mathrm{m}^{-3}$ [10]. There was a sharp seasonal variation, with the largest concentrations occurring in wintertime. Similar concentrations were found at two sites in Nevada, United States, with average $\mathrm{Hg}^{\mathrm{P}}$ being $9 \pm 7 \mathrm{pg} \mathrm{m}^{-3}$ and $13 \pm 12 \mathrm{pg} \mathrm{m}^{-3}$ [11]. The Ohio River Valley in the United States has a large number of coal-fired power plants, but $\mathrm{Hg}^{\mathrm{P}}$ was relatively low and averaged $5.29 \pm 6.04 \mathrm{pg} \mathrm{m}^{-3}$ [12]. In the highly populated and industrial city of Shanghai, China, $\mathrm{Hg}^{\mathrm{P}}$ ranged from 0.07 nanograms (ng) $\mathrm{m}^{-3}$ to $1.45 \mathrm{ng} \mathrm{m}^{-3}$ with an average of $0.56 \pm 0.22 \mathrm{ng} \mathrm{m}^{-3}$ at one site, and 0.20 to $0.47 \mathrm{ng} \mathrm{m}^{-3}$ with an average of $0.33 \pm 0.09 \mathrm{ng} \mathrm{m}^{-3}$ at another site [13]. These are among the highest values of ambient $\mathrm{Hg}^{\mathrm{P}}$ reported in the literature. In contrast, in continental outflow from China at Okinawa Island, Japan, $\mathrm{Hg}^{\mathrm{P}}$ averaged only $3.0 \pm 2.5 \mathrm{pg} \mathrm{m}^{-3}$ [14].

Weekly measurements of $\mathrm{Hg}^{\mathrm{P}}$ on Bermuda yielded low concentrations with an average of $1.3 \pm 1.7 \mathrm{pg} \mathrm{m}^{-3}$ and a range of from the limit of detection $\left(0.5 \mathrm{pg} \mathrm{m}^{-3}\right)$ to $5.2 \mathrm{pg} \mathrm{m}^{-3}$ [2]. These values are consistent with other measurements over the remote ocean $[15,16]$, but lower than at coastal locations. For example, the average $\mathrm{Hg}^{\mathrm{P}}$ value along Chesapeake Bay was an order of magnitude larger at $27 \pm 48 \mathrm{pg} \mathrm{m}^{-3}$ [2].

In the marine boundary layer (MBL) models show that the production of RGM should be enhanced due to the presence of halogens, especially $\mathrm{Br}$ and $\mathrm{Cl}$ radicals $[17,18]$. The deposition velocity of RGM 
is also 5-10 times higher than $\mathrm{Hg}^{\mathrm{P}}$ over land [19], and is likely even greater over the ocean. At Bermuda RGM averaged $50 \pm 43 \mathrm{pg} \mathrm{m}^{-3}$, which was 30-40 times higher than $\mathrm{Hg}^{\mathrm{P}}$. In comparison, the ratio of $\mathrm{RGM} / \mathrm{Hg}^{\mathrm{P}}$ is $<5$ at many remote terrestrial locations [2].

Our group has been conducting measurements of $\mathrm{Hg}^{\circ}$ in coastal New Hampshire at Thompson Farm since November 2003 and on Appledore Island in the Gulf of Maine since July 2005 [20]. Recently, RGM and $\mathrm{Hg}^{\mathrm{P}}$ measurements were added to both sites [21,22]. Currently, we are investigating the phase partitioning and cycling of atmospheric mercury in the marine boundary layer at Appledore Island. Intensive field campaigns were conducted in summer 2009, winter 2010, and spring 2010 which involved measurements of bulk filter $\mathrm{Hg}^{\mathrm{P}}$, size fractionated $\mathrm{Hg}^{\mathrm{P}}$, and $\mathrm{Hg}^{\mathrm{P}}$ with a Tekran model 1135. An important feature of these studies was that measurements were conducted in the marine and continental atmospheres to ascertain differences in phase partitioning and cycling in these two environments. Here we report seasonal comparisons of $\mathrm{Hg}^{\mathrm{P}}$ measured with the manual filter method and the automated Tekran system.

\section{Results and Discussion}

\subsection{Campaign Details}

During summer 2009 studies were conducted on Appledore Island in the Gulf of Maine and at and the inland site Thompson Farm. Tekran speciated atmospheric mercury systems were operated continuously at each site. At both sites two cascade impactors were run twice for seven days each. Bulk filter samples were collected with three hour time resolution. Ozone $\left(\mathrm{O}_{3}\right)$ and carbon monoxide (CO) were measured with one minute time resolution. Stainless steel canisters were used to collect whole air samples once an hour for determination of hydrocarbons, halocarbons, alkyl nitrates, and selected sulfur gases. The analyses were conducted in the trace gas laboratory at the University of New Hampshire. At Thompson Farm 200 trace gases are measured year-round. During the intensive period in summer 2009 canister samples were collected and continuous measurement of oxygenated compounds was conducted using proton transfer reaction mass spectrometry. The various scenarios of data availability during each intensive period are summarized in Table 1.

Table 1. Campaign details.

\begin{tabular}{|c|c|c|c|c|}
\hline Date & Location & Bulk Filter & Impactor & Trace Gases \\
\hline 21 July-9 August 2009 & $\begin{array}{l}\text { Appledore } \\
\text { Island } \\
\text { Thompson } \\
\text { Farm }\end{array}$ & $\begin{array}{l}3 \text { hour resolution } \\
\text { No }\end{array}$ & $\begin{array}{l}7 \text { day resolution } \\
7 \text { day resolution }\end{array}$ & $\begin{array}{l}\text { Hourly Canisters, } \\
\mathrm{O}_{3}, \mathrm{CO} \\
\text { PTR-MS, } \mathrm{O}_{3}, \mathrm{CO}\end{array}$ \\
\hline $\begin{array}{l}21 \text { January-10 February } \\
2010\end{array}$ & $\begin{array}{l}\text { Thompson } \\
\text { Farm }\end{array}$ & 24 hour resolution & 10 day resolution & PTR-MS, $\mathrm{O}_{3}, \mathrm{CO}$ \\
\hline 5 April-25 April 2010 & $\begin{array}{l}\text { Thompson } \\
\text { Farm }\end{array}$ & 24 hour resolution & 10 day resolution & $\begin{array}{l}\text { Continuous GC } \\
\text { PTR-MS, } \mathrm{O}_{3}, \mathrm{CO}\end{array}$ \\
\hline
\end{tabular}




\subsection{Campaign Results}

The time series record of $\operatorname{Hg}^{\mathrm{P}}$ measured on Appledore Island in summer 2009 with the Tekran and filter methods are shown in Figure 1. We report $\mathrm{Hg}^{\mathrm{P}}$ in terms of its mixing ratios in parts per quadrillion by volume (ppqv). Further, we note that $1 \mathrm{ng} \mathrm{m}^{-3}$ of $\mathrm{Hg}$ is equal to $112 \mathrm{ppqv}$. The Tekran rarely found $\mathrm{Hg}^{\mathrm{P}}$ to be $>1 \mathrm{ppqv}$, while the filter determined values were up to 3 ppqv on several occasions. To check for a positive artifact with the filter measurements from uptake of RGM, we also show in Figure $1 \mathrm{Hg}^{\mathrm{P}}$ measured with the filter minus the corresponding integrated RGM value. It is apparent that the higher values obtained with the filter is not due to uptake of RGM. It is interesting that at times the two measurements show trends in the opposite direction and that the Tekran often was reading zero ppqv for hours at a time. The calibration of the Tekran was checked using a Tekran model 2505 Saturated Mercury Vapor Calibration Unit (i.e., direct injections from the headspace of a thermoelectrically cooled $\mathrm{Hg}^{\circ}$ reservoir) and it was found to be within $\pm 2 \%$. Thus, calibration was ruled out as a cause for the discrepancies.

Figure 1. Time series of Tekran and filter measurements of $\mathrm{Hg}^{\mathrm{P}}$ at Appledore Island during summer 2009.

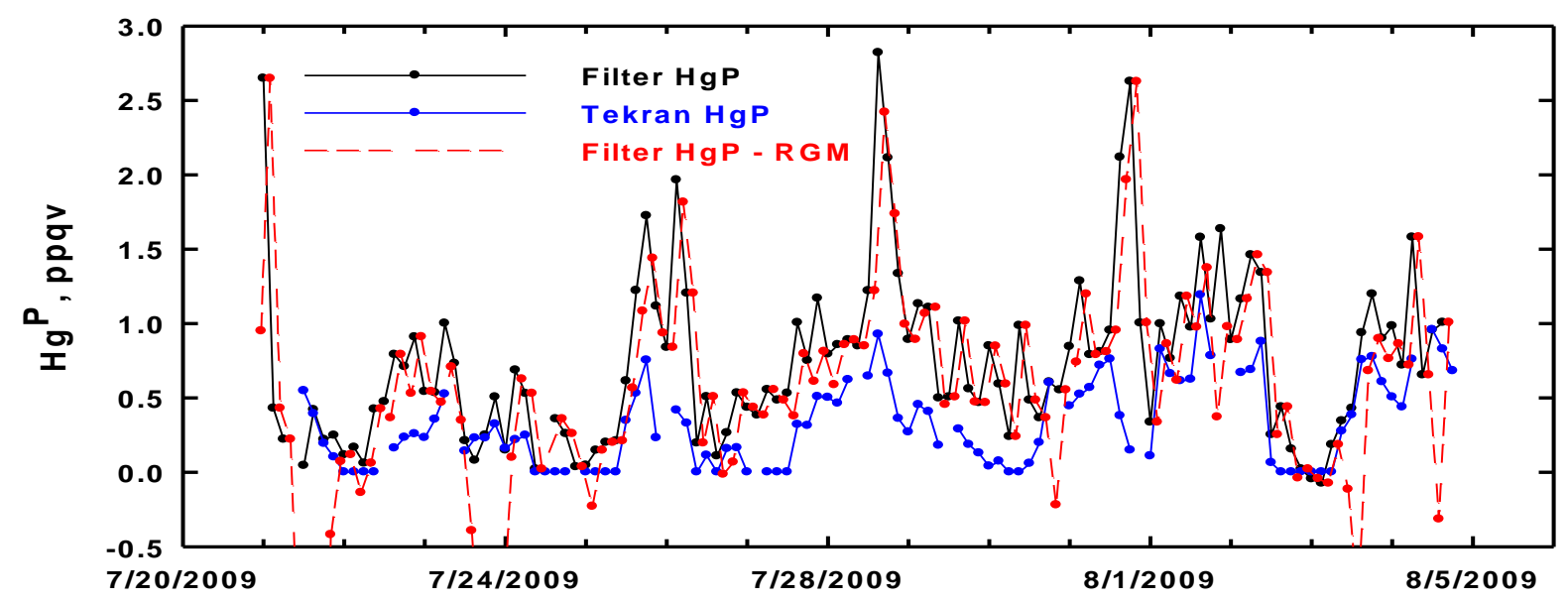

The data for $\mathrm{Hg}^{\mathrm{P}}$ at Thompson Farm in winter is presented in Figure 2. The Tekran data was integrated to correspond better to the 24 hour filter samples. In general, the trends in the two $\mathrm{Hg}^{\mathrm{P}}$ measurements were similar over the study period. Although there was better agreement in the two measurements of $\mathrm{Hg}^{\mathrm{P}}$ in winter compared to summer, the Tekran only found $\mathrm{Hg}^{\mathrm{P}}$ to be $>1$ ppqv two times. As in summer, there seems to be little influence of RGM on the filter-based $\mathrm{Hg}^{\mathrm{P}}$ measurements. During the first couple of days of the study period there was close correlation with $\mathrm{Hg}^{\mathrm{P}}$ and condensation nuclei (CNC)-black carbon. Afterwards, the three aerosol components exhibited individual characteristics suggesting that occasionally $\mathrm{Hg}^{\mathrm{P}}$ was probably associated with black carbon. The bulk CNC also showed limited correspondence with $\mathrm{Hg}^{\mathrm{P}}$, which is probably not surprising considering the ultra-trace quantities of $\mathrm{Hg}^{\mathrm{P}}$ in the atmosphere.

In springtime the situation was much different in that the two methods for measuring $\mathrm{Hg}^{\mathrm{P}}$ tracked each other throughout the entire study period (Figure 3). However, overall the filter still yielded higher values of $\mathrm{Hg}^{\mathrm{P}}$ compared to the Tekran. The same pattern emerged with the largest difference in the two values occurring when the filter yielded the highest mixing ratios of $\mathrm{Hg}^{\mathrm{P}}$. As was the case in winter, 
there was little correspondence between $\mathrm{Hg}^{\mathrm{P}}$ and CNC. In springtime a positive artifact from RGM uptake on the filter could be a problem. When the total RGM passing through the filter was subtracted from the filter $\mathrm{Hg}^{\mathrm{P}}$ it resulted in some values that were close or even significantly less than the Tekran $\mathrm{Hg}^{\mathrm{P}}$. Since this was not the case in the other seasons, it is caused by the highest annual RGM values occurring in spring (Table 2) [21].

Figure 2. Time series record of various aerosol measurements at Thompson Farm during winter 2010. The Tekran $\operatorname{Hg}^{\mathrm{P}}$ measurements were integrated to correspond to the 24-hour filter samples for $\mathrm{Hg}^{\mathrm{P}}$.

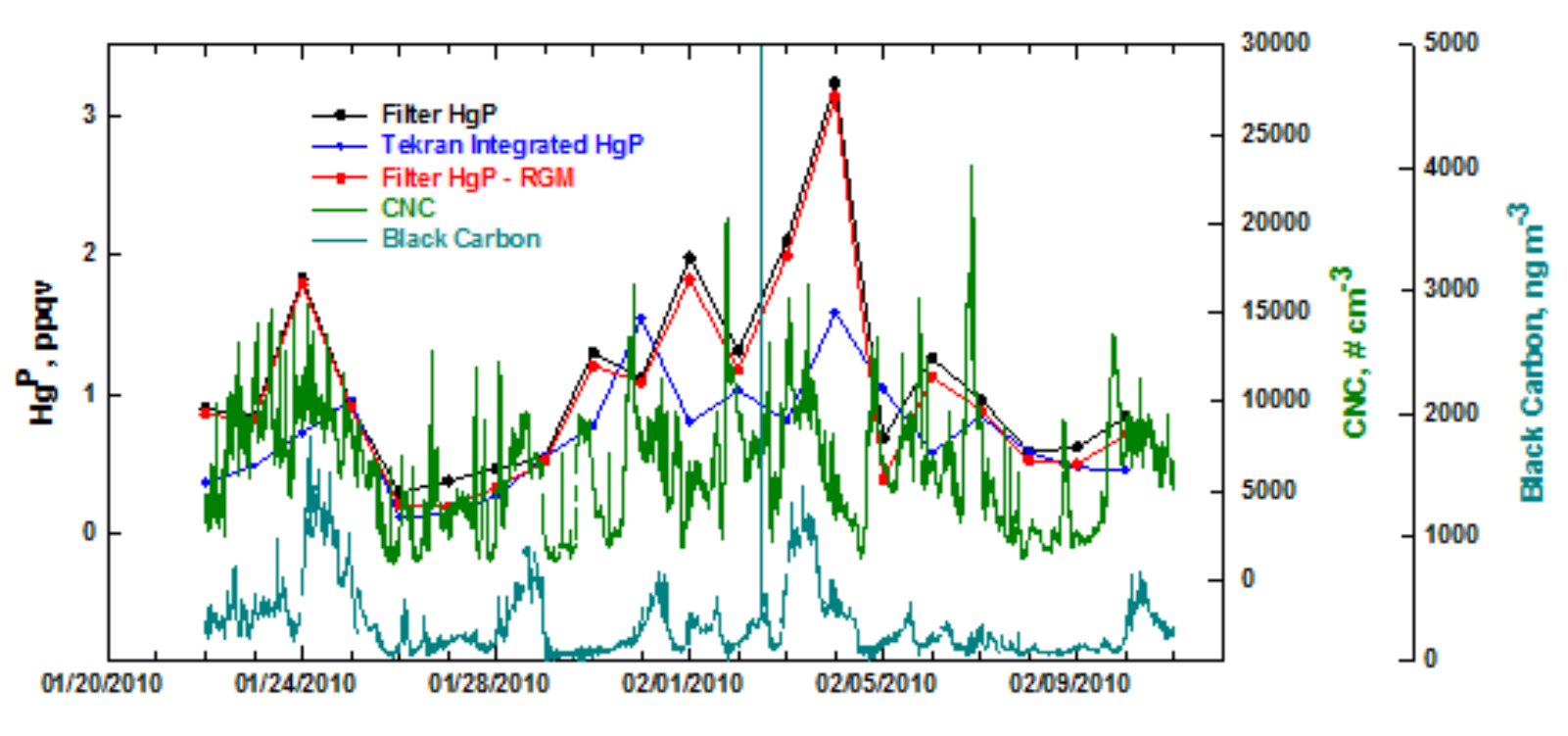

Figure 3. Time series of various aerosol measurements at Thompson Farm in spring 2010. The Tekran $\mathrm{Hg}^{\mathrm{P}}$ data was integrated to correspond to the 24 hour filter samples for $\mathrm{Hg}^{\mathrm{P}}$.

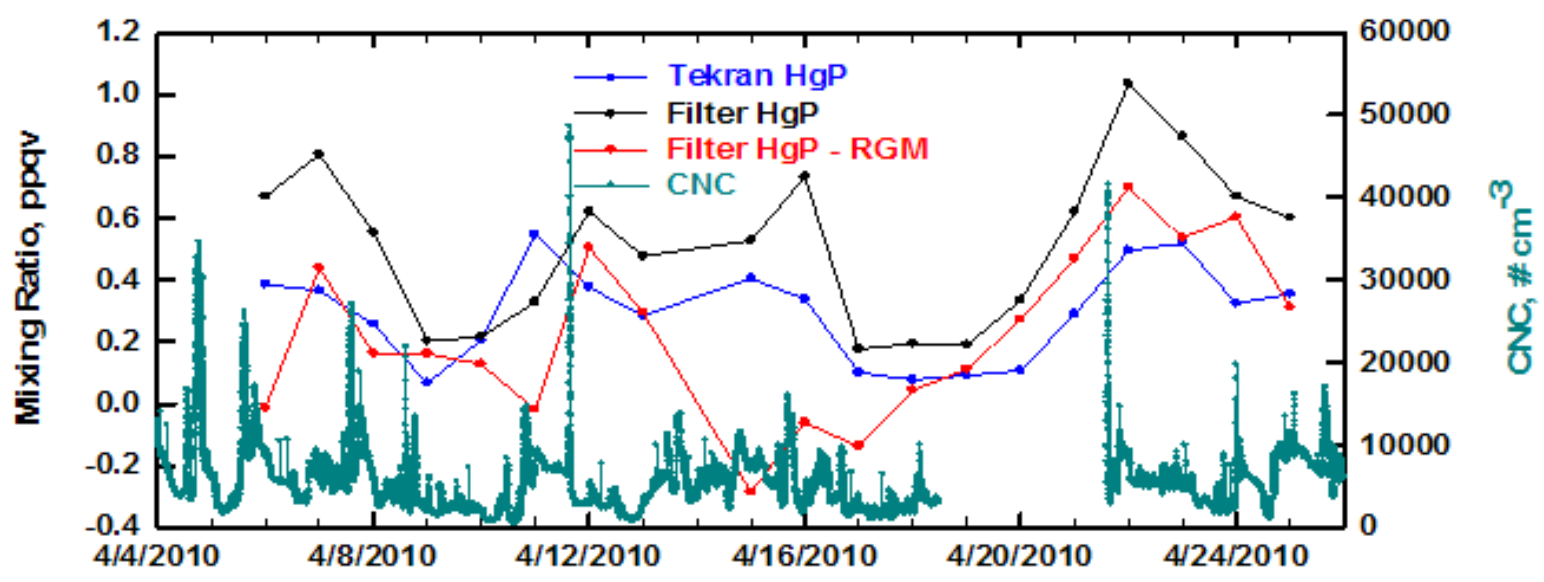

A statistical summary of the seasonal data is presented in Table 2. We estimated that the filter data has an overall uncertainty of $\sim \pm 20 \%$. To arrive at this estimate we propagated the errors associated with the analytical analysis, variability in the filter blank, multiple analyses of sample extracts, and the flow meter uncertainty. The accuracy of the filter $\mathrm{Hg}^{\mathrm{P}}$ should be better than $5 \%$ since a certified reference was used in the analysis. The uncertainty of the Tekran unit is not well established, but 
periods of relatively constant ambient $\mathrm{Hg}^{\mathrm{P}}$ mixing ratios indicate that it could be as good as $\sim \pm 5 \%$. As an example of this, look at the variation in the Tekran $\mathrm{Hg}^{\mathrm{P}}$ data from April 17 to April 20 in Figure 3. Although the mixing ratios are very low, the Tekran provided consistent values over this time period. In addition, the blank subtraction was essentially zero except for a few instances. Thus, a high blank was not responsible for the lower Tekran values of $\mathrm{Hg}^{\mathrm{P}}$. However, a better estimate of it should be obtained by operating two units side-by-side. We intend to do this in the future. Based on these uncertainty estimates, it is readily apparent that the filter yielded higher values of $\mathrm{Hg}^{\mathrm{P}}$ than the Tekran unit. The seasonal comparison of $\mathrm{Hg}^{\mathrm{P}}$ values determined with the filter show that while winter has the highest mixing ratios, summer is lower by $\sim 25 \%$ and spring $\sim 40 \%$. A much different picture results from the Tekran data. Winter clearly stands out as the highest, with summer and spring lower by $\sim 60 \%$. The greatest difference in the filter and Tekran $\mathrm{Hg}^{\mathrm{P}}$ values occurred in the marine environment. This is likely caused by the presence of coarse sea salt aerosol which is probably not passed with high efficiency through the RGM denuder. The size distribution of $\mathrm{Hg}^{\mathrm{P}}$ determined with cascade impactor sampling showed that $\sim 90 \%$ of the $\mathrm{Hg}^{\mathrm{P}}$ was contained in aerosols with aerodynamic diameters $>2$ micrometer $(\mu \mathrm{m})$ at Appledore Island [22]. Thus, we attribute the 3-fold lower Tekran mixing ratios partially to this phenomenon. This is a large enough difference to inhibit accurate assessment of atmospheric mercury cycling and lifetimes in the marine boundary layer.

Table 2. Statistical summary as a function of season. All values are stated in ppqv.

\begin{tabular}{|lllllll|}
\hline Season & Filter & $\mathrm{Hg}^{\mathrm{P}}$ & Tekran & $\mathrm{Hg}^{\mathrm{P}}$ & $\mathrm{RGM}$ & \\
& Median & Range & Median & Range & Median & Range \\
\hline Summer & 0.70 & $0.05-2.8$ & 0.25 & $0.0-0.96$ & 0.0 & $0.0-3.5$ \\
Winter & 0.92 & $0.30-3.2$ & 0.62 & $0.0-2.8$ & 0.07 & $0.0-0.46$ \\
Spring & 0.54 & $0.18-1.0$ & 0.28 & $0.0-0.95$ & 0.14 & $0.0-2.3$ \\
\hline
\end{tabular}

A summary plot is presented in Figure 4 which shows the seasonal relationships between filter $\mathrm{Hg}^{\mathrm{P}}$ and the integrated Tekran $\mathrm{Hg}^{\mathrm{P}}$. We did not observe loss of mercury from the three-hour collection time periods for the filter, but the 24-hour and cascade impactor samples did have measurable losses presumably from halogen reactions [7]. This is discussed in detail in the companion paper by Feddersen [22]. We note that despite the losses from the 24-hour filters, the filter data were still provided higher mixing ratios of $\mathrm{Hg}^{\mathrm{P}}$ as shown below.

The summer and winter data are the most disparate, while the spring data were more comparable. Overall, the filter $\mathrm{Hg}^{\mathrm{P}}$ values were on the average $21 \%$ higher than the Tekran $\mathrm{Hg}^{\mathrm{P}}$, and $>90 \%$ of the data lie outside of $\pm 25 \%$ region surrounding the 1:1 line. In some cases the filter values were as much as 3-fold greater, with $<5 \%$ of the points falling on the 1:1 line. A common characteristic in all seasons was that the Tekran only yielded a total of 6 data points above 1 ppqv (i.e., $\sim 4 \%$ of the observations), and had $\sim 25 \%$ of its measurements as below the limit of detection $(<0.1-0.2$ ppqv). In comparison, the filter always had detectable $\mathrm{Hg}^{\mathrm{P}}$ above the blank level of $0.05 \mathrm{ppqv}$, and was undenuded to minimize positive artifacts from $\mathrm{O}_{3}$ reactions [23]. 
Figure 4. The relationship between filter $\mathrm{Hg}^{\mathrm{P}}$ and the integrated Tekran $\mathrm{Hg}^{\mathrm{P}}$ during the summer, winter, and spring seasons. The dashed line represents the 1:1 relationship and the two solid lines surrounding it mark the $\pm 25 \%$ boundaries. The other solid line represents a linear fit of between the filter $\mathrm{Hg}^{\mathrm{P}}$ and the integrated Tekran $\mathrm{Hg}^{\mathrm{P}}$.

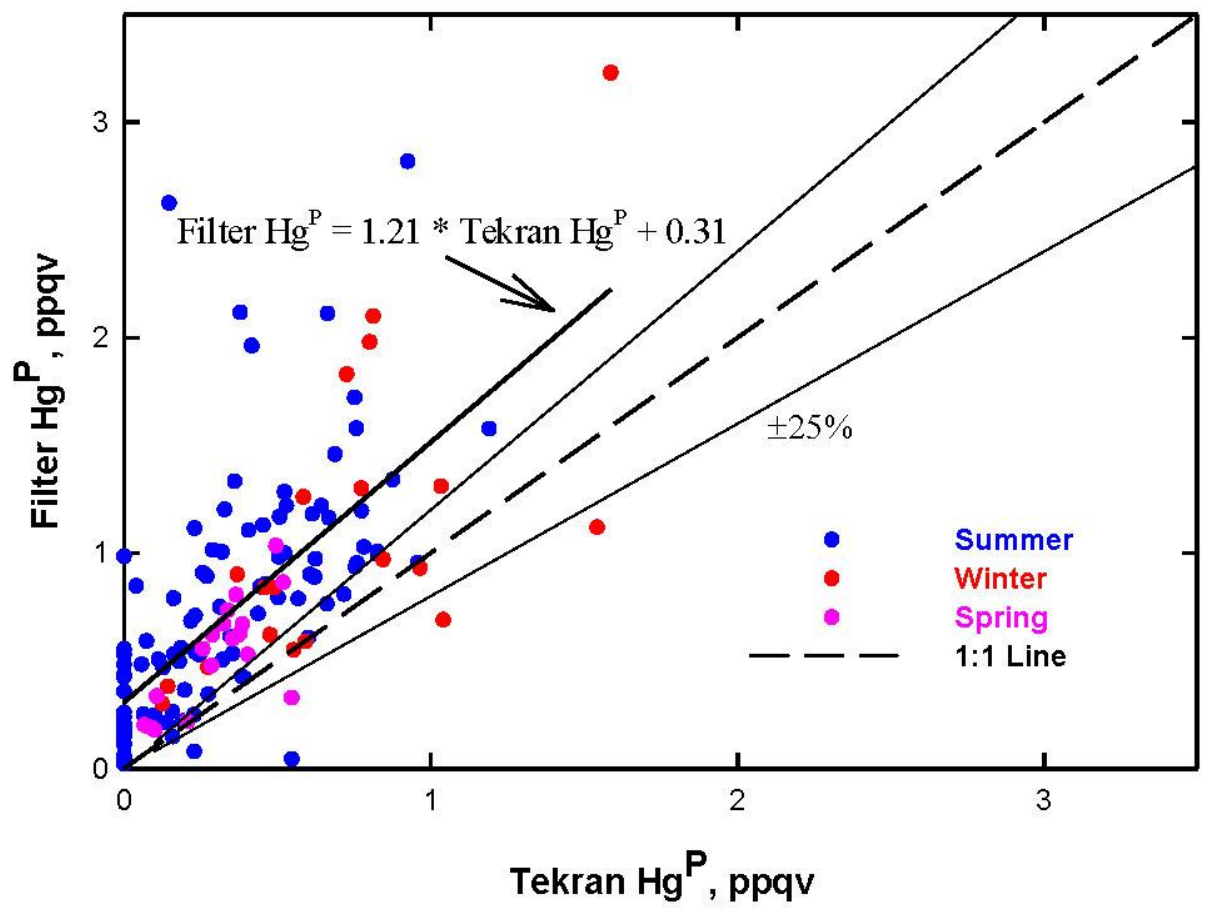

\section{Discussion}

The top panel of Figure 5 shows summer data at Appledore and we present some key relationships for the two measurement techniques of $\mathrm{Hg}^{\mathrm{P}}$. First, the difference between the filter and ${\mathrm{Tekran} \mathrm{Hg}^{\mathrm{P}}}^{\mathrm{P}}$ values has a median of $0.35 \mathrm{ppqv}$, and ranges from zero to $2.5 \mathrm{ppqv}$. There are only two data points (on July 21 and 23) where the Tekran $\mathrm{Hg}^{\mathrm{P}}$ was greater than $\mathrm{Hg}^{\mathrm{P}}$ measured with the filter. The largest differences occurred when the filter-based $\mathrm{Hg}^{\mathrm{P}}$ produced the highest mixing ratios. Second, the total ng of $\mathrm{Hg}$ on the filter was calculated and compared to the total ng of RGM if the filter had retained it with $100 \%$ efficiency throughout the whole sampling interval. Early and late in the sampling period the amount of RGM would have been equal to or greater than the total amount of filter measured $\mathrm{Hg}^{\mathrm{P}}$. Throughout the rest of the sampling time frame, including the two largest peaks in $\mathrm{Hg}^{\mathrm{P}}$, RGM would seem to be a non-issue. We conclude that a positive RGM artifact is possible occasionally, but in general it does not appear to be a major problem.

In the middle panel of Figure 5 the time series of selected hydrocarbons and halocarbons are depicted over the two week sampling interval. Isoprene $\left(\mathrm{C}_{5} \mathrm{H}_{8}\right)$ is a tracer of biogenic emissions, or continental air. Acetylene $\left(\mathrm{C}_{2} \mathrm{H}_{2}\right)$ is an indicator of combustion, and tetrachloroethylene $\left(\mathrm{C}_{2} \mathrm{Cl}_{4}\right)$ is emitted from urban sources such as dry cleaning [24]. It is clear that biogenic emissions are not associated with the largest peaks in $\mathrm{Hg}^{\mathrm{P}}$. The spike in $\mathrm{Hg}^{\mathrm{P}}$ on July 28 also has concomitant peaks in $\mathrm{C}_{2} \mathrm{H}_{2}$ and $\mathrm{C}_{2} \mathrm{Cl}_{4}$ that suggest the $\mathrm{Hg}^{\mathrm{P}}$ might be derived from urban activities. There is also significant $\mathrm{O}_{3}$ associated with this episode (Figure 5, bottom panel). Other large peaks in $\mathrm{Hg}^{\mathrm{P}}$ on July 21 and 31 do not appear to have subsequent peaks in any of the tracer compounds, although the 31 st also has 
elevated $\mathrm{O}_{3}$ and $\mathrm{CO}$. For the closely spaced double peaks in $\mathrm{Hg}^{\mathrm{P}}$ around July $26, \mathrm{C}_{2} \mathrm{Cl}_{4}$ showed similar albeit not identical ones. Interestingly, the sustained peak in $\mathrm{C}_{2} \mathrm{Cl}_{4}$ around July 23 shows little

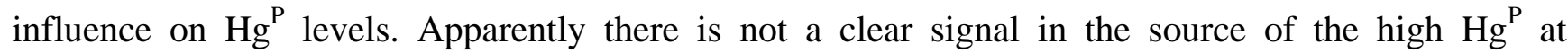
Appledore Island. Urban sources could account for a fraction of the elevated levels, but the picture is far from being straightforward.

Figure 5. Top Panel - Comparison of total $\mathrm{Hg}$ on filter and from potential collection of all RGM on filter during summer sampling interval on Appledore Island. Middle Panel—Selected hydrocarbon/halocarbon time series. Bottom Panel-Times series of $\mathrm{O}_{3}$ and CO.

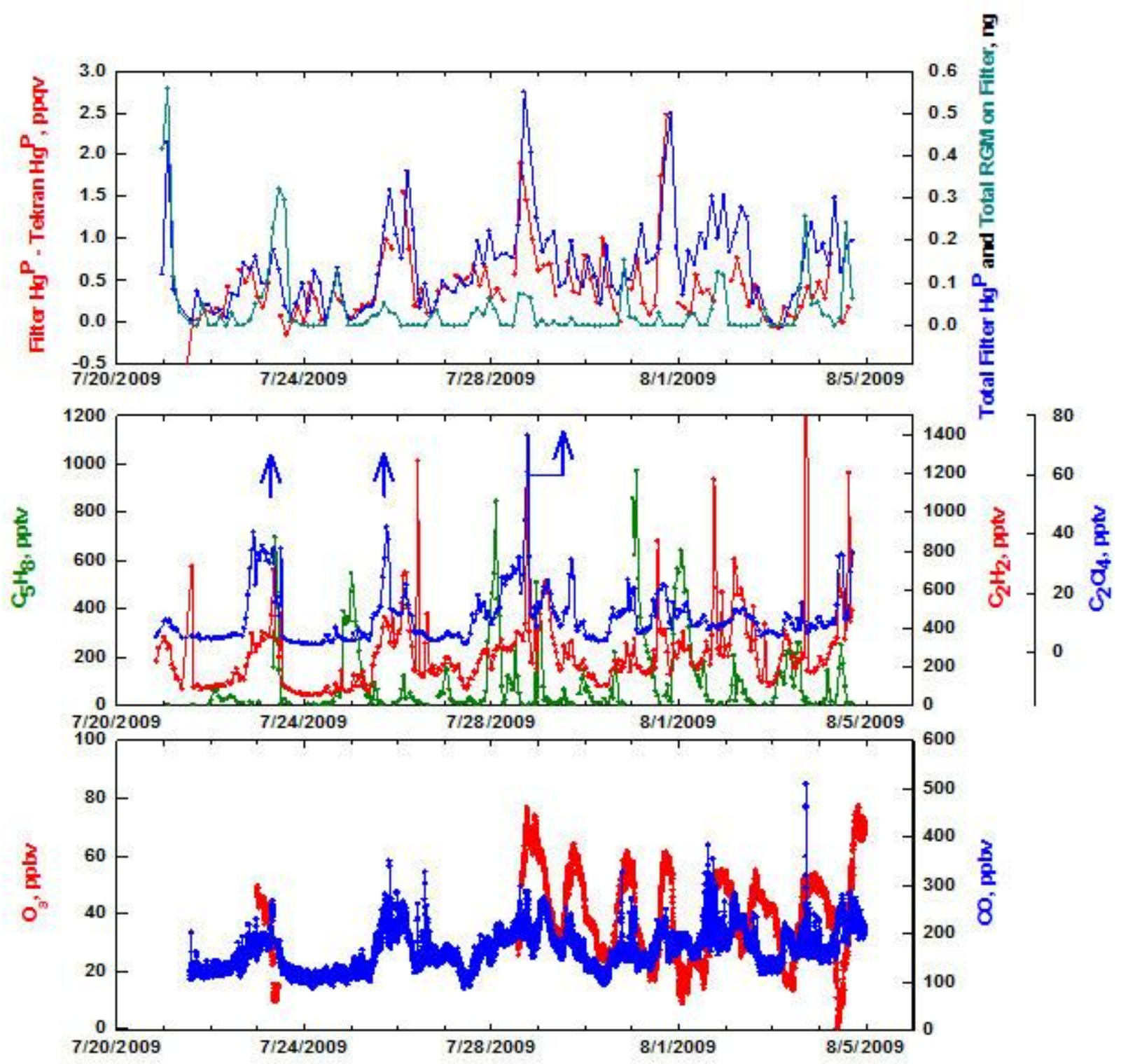

Backward trajectories were calculated for $\mathrm{Hg}^{\mathrm{P}}$ peaks that occurred on July 21, 28, and 31 at Appledore Island. The trajectories indicate that these air masses were likely influenced by urban/industrial sources along the U.S. east coast. The July 22 case showed an enhanced and sustained 
elevation in $\mathrm{C}_{2} \mathrm{Cl}_{4}$, an urban tracer, but little increase in $\mathrm{Hg}^{\mathrm{P}}$. The trajectories indicate the possibility that the air passed east of Boston and might not have been directly affected by local emission sources.

In Figure 6 we present the wintertime relationship between total $\mathrm{ng}$ of $\mathrm{Hg}^{\mathrm{P}}$ on the filter and total ng RGM Hg if it was retained $100 \%$ on the filter. There are a few instances where a positive RGM artifact could be important, but in general it does not appear to be a factor. The two largest peaks in filter $\mathrm{Hg}^{\mathrm{P}}$, on January 24 and February 4, have concurrently high mixing ratios of many oxygenated compounds and hydrogen cyanide $(\mathrm{HCN})$. The largest peak on February 4 exhibited biomass burning characteristics with concomitant 1 ppbv enhancements in $\mathrm{HCN}$ and acetonitrile $\left(\mathrm{CH}_{3} \mathrm{CN}\right)$. Acetic acid $\left(\mathrm{CH}_{3} \mathrm{COOH}\right)$ was also highly elevated and it is known to have biomass burning as a source [25]. Surprisingly, the biogenic compounds isoprene $\left(\mathrm{C}_{5} \mathrm{H}_{8}\right)$ and terpenes were enhanced 0.5 and $1 \mathrm{ppbv}$ respectively in the middle of winter. These compounds have relatively short lifetimes, and in winter they are usually near their limit of detection at Thompson Farm [26]. Backward trajectories indicate that the air originated over central Canada. However, Canadian fire count records indicated that there no wildfires burning there for weeks either side of February 4 (http://www.ciffc.ca/ index.php?option=com_content\&task=view\&id=26\&Itemid=28). In addition, it is unlikely that the biomass-like emissions could be attributed to emissions from a coal-fired steam power plant since mixing ratios of $\mathrm{CO}_{2}$ and $\mathrm{SO}_{2}$ (not shown) were flat throughout this time interval.

Particularly perplexing is the source of the enhanced biogenic compounds. Air temperature varied from -1 to $-10{ }^{\circ} \mathrm{C}$ on February 4 at Thompson Farm. This would seem to rule out a rare warm winter day with a spike in biogenic emissions. One possible source could be local wood burning in wood stoves and fireplaces, but nitric oxide (NO) and $\mathrm{CO}$ exhibited low and flat mixing ratios on February $4^{\text {th }}$. Thus, it is unclear as to the source(s) of the enhanced $\mathrm{Hg}^{\mathrm{P}}$ and other chemical species.

The two other largest peaks in filter $\mathrm{Hg}^{\mathrm{P}}$ that occurred on January 24 and February 1 have source regions over northern New England and the Ohio Valley area respectively. These peaks also appear to contain biomass burning characteristics but again little NO. In winter the lifetime of NO is about 1.5 days [27], which opens up the possibility of aged biomass burning emissions from wood stoves and fireplaces across the source regions. This could also explain the peak in $\mathrm{Hg}^{\mathrm{P}}$ on February 4.

In springtime the variations in filter $\mathrm{Hg}^{\mathrm{P}}$ were tracked well by $\mathrm{C}_{2} \mathrm{H}_{2}, \mathrm{C}_{2} \mathrm{Cl}_{4}$, oxygenated compounds, and $\mathrm{CO}$ (Figure 7). In general, when these compounds indicated pollution plumes were present, the filter $\mathrm{Hg}^{\mathrm{P}}$ was also enhanced. The correspondence with $\mathrm{C}_{5} \mathrm{H}_{8}$ was marginal, with better correlations with combustion and anthropogenic tracers. There are peaks in $\mathrm{O}_{3}$ that correspond to the pollution plumes, and indicate active photochemistry was occurring. The diurnal trend in $\mathrm{O}_{3}$ is caused by production in daytime and deposition and titration at night under the nocturnal inversion [28]. The active photochemistry and presence of marine influences periodically at Thompson Farm in springtime produces the highest RGM mixing ratios during this season [29]. In fact, during April 14-16 the RGM was greater than the $\mathrm{Hg}^{\mathrm{P}}$ measured with either method. The filter $\mathrm{Hg}^{\mathrm{P}}$ during this time period is particularly prone to a positive artifact from RGM uptake on the filter during sampling. Note that the filter and Tekran $\mathrm{Hg}^{\mathrm{P}}$ data are very similar during this time period and a t-test showed that they were not statistically different $(\mathrm{p}=0.01)$. Since presumably the Tekran $\mathrm{Hg}^{\mathrm{P}}$ is not subject to interference from RGM, this suggests the filter data were not impacted by an RGM positive artifact. In the laboratory we flowed $\mathrm{Hg}^{0}$ and $\mathrm{HgCl}_{2}$ in zero air ( 200 ppqv) from a permeation source through blank 
fluoropore filters and did not observe uptake of $\mathrm{Hg}^{0}$ or RGM by the Teflon filter. Thus, if uptake occurs under ambient conditions it must be caused by absorption/reaction with collected aerosols.

The four largest peaks in filter $\mathrm{Hg}^{\mathrm{P}}$ occurred on April 7, 12, 16, and 22 in spring 2010. Three of these peaks had entirely different source regions based on 24-hour backward trajectories. The trajectories on April 7 and February 3 indicate that the pollution including $\mathrm{Hg}^{\mathrm{P}}$ likely originated from anthropogenic sources in the Ohio Valley and Northeast urban corridor. On April 16 the high $\mathrm{Hg}^{\mathrm{P}}$ probably can be attributed to local Boston sources. The peak on April 12 is uncertain to its source, and has the same source region as the winter peaks in $\mathrm{Hg}^{\mathrm{P}}$. Nonetheless, it appears that combustion, whether it is natural or anthropogenic, is a common source for $\mathrm{Hg}^{\mathrm{P}}$.

The size distribution of the $\mathrm{Hg}^{\mathrm{P}}$ is reported in a companion paper by Feddersen et al. [22]. We briefly summarize the salient results here. In summer, the size distribution of $\mathrm{Hg}^{\mathrm{P}}$ was mainly in the coarse (i.e., sea salt) fraction $(>1 \mu \mathrm{m}$ ) between $2-10 \mu \mathrm{m}$ at both Appledore Island and Thompson. This was shifted almost entirely to the fine fraction $(<1 \mu \mathrm{m})$ below $0.5 \mu \mathrm{m}$ in winter, with little detectable in the coarse sizes. In spring, there was a mixture of fine and coarse fractions. The coarse aerosols at both locations are dominated by sea salt, which is rarely present at Thompson Farm in winter. Together the results of this work and that of Feddersen et al. [22] indicate that the consistently lower $\mathrm{Hg}^{\mathrm{P}}$ measured by the Tekran cannot be explained solely by poor passing efficiency of coarse aerosols in the automated unit. We have demonstrated that the summer and winter data are of similar disparities, yet each season is dominated by different aerosol size preferences for $\mathrm{Hg}^{\mathrm{P}}$. A possible explanation for the lower $\mathrm{Hg}^{\mathrm{P}}$ values obtained with the Tekran unit is volatilization of $\mathrm{Hg}^{0} / \mathrm{RGM}$ from aerosols as they pass through the heated RGM denuder. This could occur as water is volatilized with associated release of $\mathrm{Hg}^{0} / \mathrm{RGM}$ back to the gas phase [30].

We examined the data for possible artifacts related to variations in relative humidity. At Appledore Island the humidity is more-or-less constant at about 80\%. At Thompson Farm the relative humidity reaches $100 \%$ on most summer nights and decreases to half that in daytime. The Tekran data and the difference between the filter and Tekran were examined for a humidity influence. As aerosols passed through the heated RGM denuder, water might evaporate from aerosols with associated mercury yielding low $\mathrm{Hg}^{\mathrm{P}}$ for the Terkan system. However, we could not identify any influence of humidity, and concluded that this was of minor importance. 
Figure 6. Top panel-Comparison of total $\mathrm{Hg}$ from potential collection of all RGM on filter during the winter sampling interval at Thompson Farm. Middle panels-Time series of selected hydrocarbon/halocarbons/oxygenates/HCN. Bottom panel-Time series of $\mathrm{O}_{3}$ and $\mathrm{CO}$.
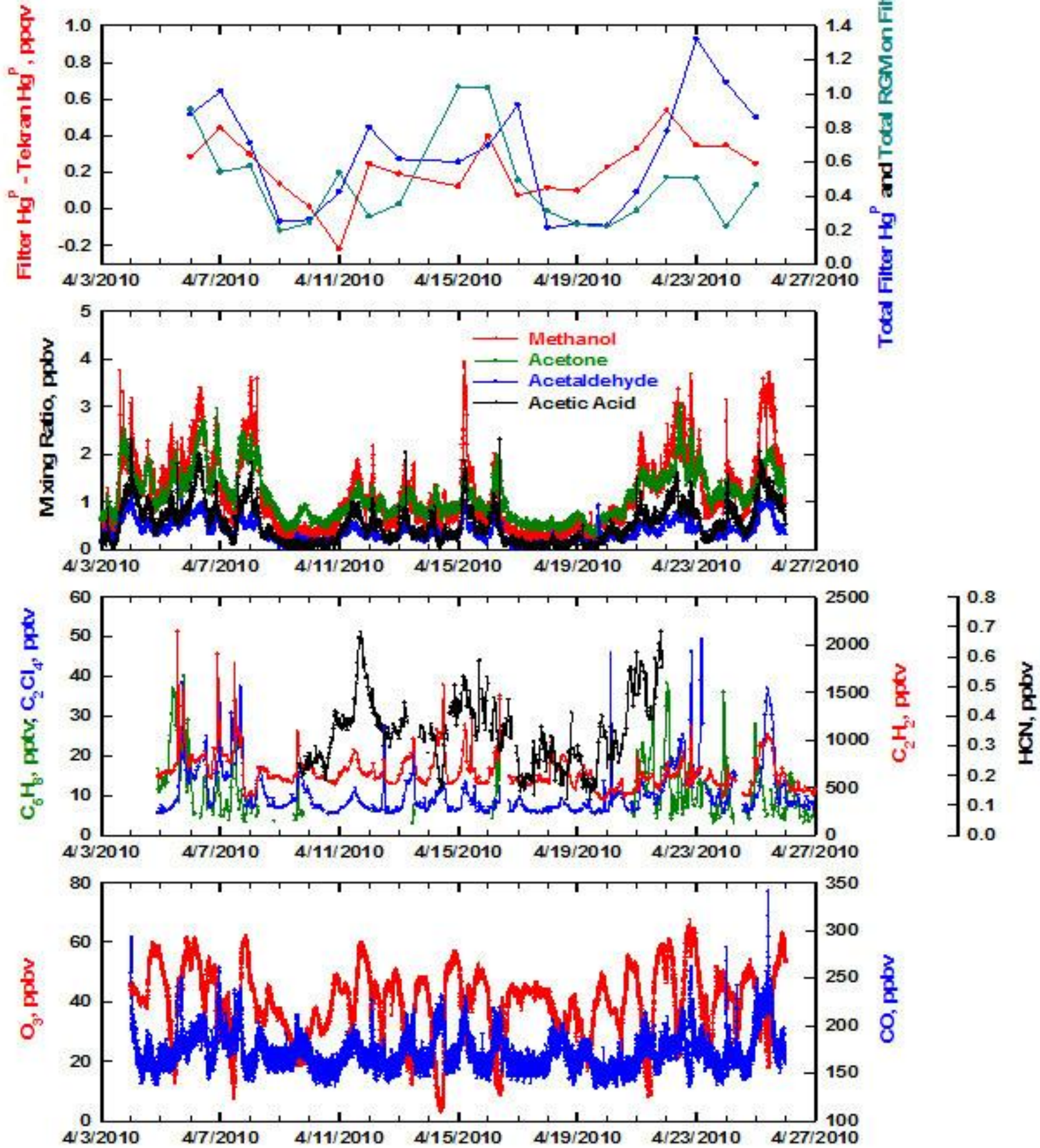
Figure 7. Top panel-Comparison of total $\mathrm{Hg}$ from potential collection of all RGM on filter during the spring sampling interval at Thompson Farm. Middle panels-Time series of selected hydrocarbon/halocarbons/oxygenates/HCN. Bottom panel-Time series of $\mathrm{O}_{3}$ and $\mathrm{CO}$.
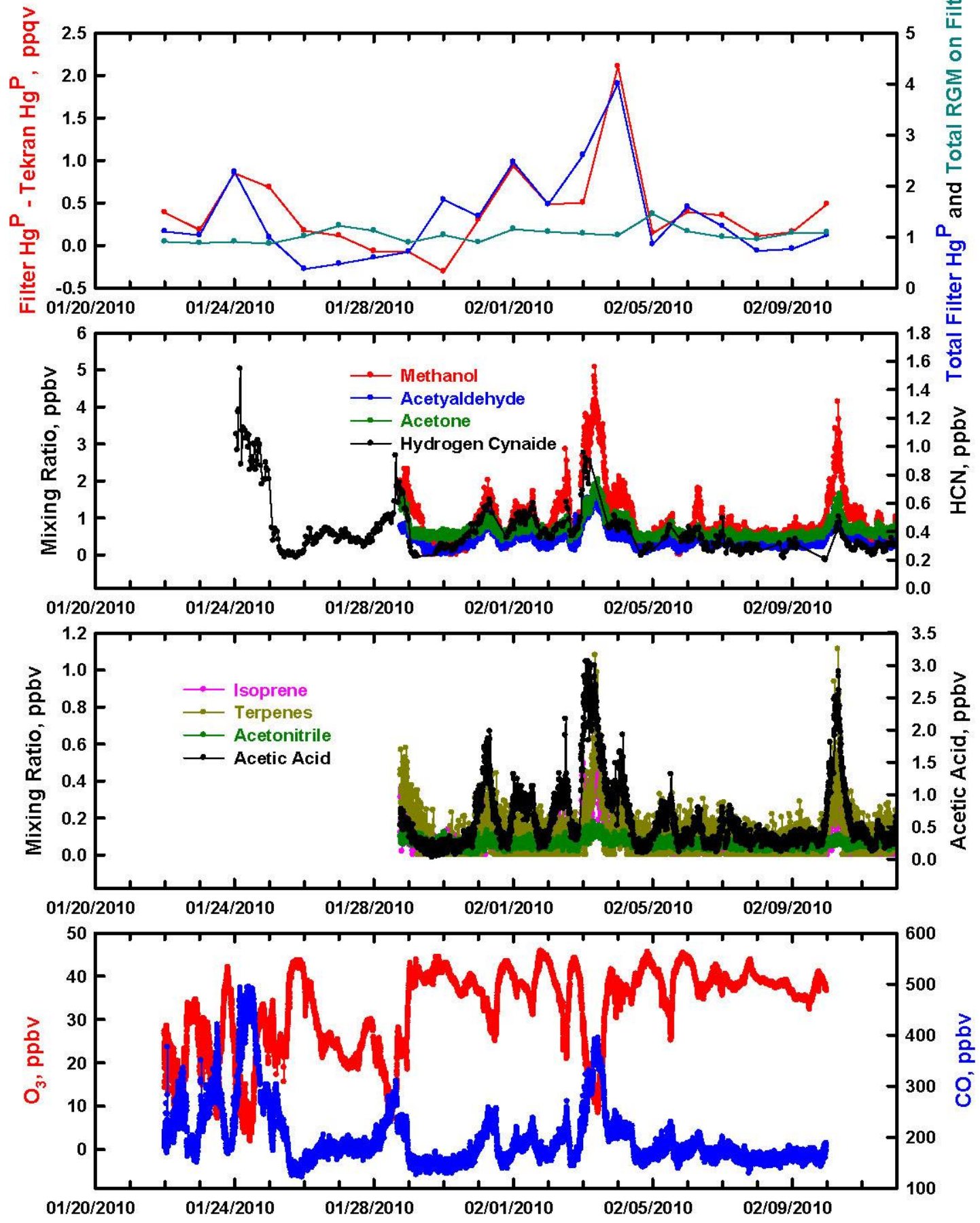

\section{Experimental Section}

Two sites in the AIRMAP observing network (www.airmap.unh.edu) were utilized for measurements of speciated atmospheric mercury. The first was at Thompson Farm $\left(43.1078^{\circ} \mathrm{N}\right.$, 
$70.9517^{\circ} \mathrm{W}$ ) which is located about $25 \mathrm{~km}$ inland from the Atlantic coastline. The second was on Appledore Island $\left(42.97^{\circ} \mathrm{N}, 70.62^{\circ} \mathrm{W}\right)$ about $12 \mathrm{~km}$ offshore from New Hampshire in the Gulf of Maine. The geographic locations of these sites are shown in Figure 8. During certain time periods the Thompson Farm location is impacted by a marine influence, as indicated by the presence of tracer compounds such as $\mathrm{CHBr}_{3}$ and DMS [31,32]. Similarly, Appledore Island is under continental influence $\sim 30 \%$ of the time during summertime [33]. In general, wind speeds were only a few m s during the campaigns.

At both sites we operate a Tekran system which consists of a model 1130 to measure RGM, a model 1135 to measure $\mathrm{Hg}^{\mathrm{P}}$, and 2537A cold vapor fluorescence detector. On Appledore all instruments are powered year-round by electricity generated by a custom wind turbine system [34]. Elemental Hg was quantified with a five minute time resolution. Reactive $\mathrm{Hg}$ and $\mathrm{Hg}^{\mathrm{P}}$ were determined using a two hour sampling and one hour flushing and desorption sequences. The instruments were configured and operated identically at both sites according to the U.S. Environmental Protection Agency Standard Operating Procedures for Analysis of Gaseous and Fine Particulate-Bound Mercury [35], with one modification. Instead of using the Tekran commercial water removal cartridge system, we developed a custom cold finger unit which operates autonomously only producing water as a waste by-product. The system is extremely clean and we believe that it helps keep the blank on the speciated measurements at zero. Thus, blank subtraction is rarely required.

Figure 8. Region of interest for this study along coastal New Hampshire.

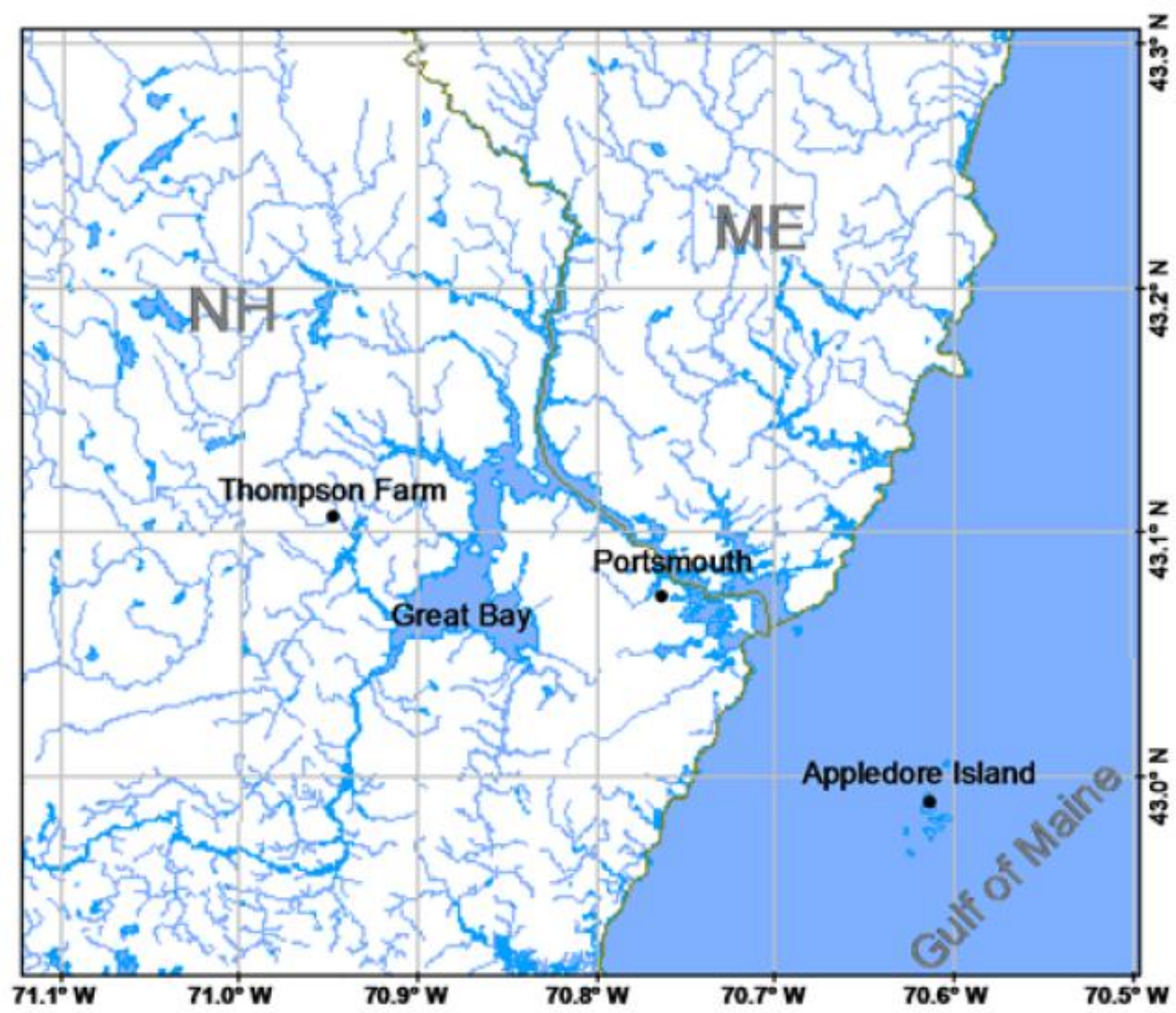


Calibration of the 2537A unit was conducted automatically every 24 desorption cycles, and this was verified every six months using a Tekran model 2505 Saturated Mercury Vapor Calibration Unit (i.e., direct injection from the headspace of a thermoelectrically cooled $\mathrm{Hg}^{0}$ reservoir) to confirm absolute calibration.

The Tekran units are typically equipped with an elutriator inlet with an acceleration jet to remove aerosols $>2.5 \mu \mathrm{m}$ so that only fine $\mathrm{HgP}$ is measured. This is not a desirable design, especially in the marine environment with sea salt in the $2-10 \mu \mathrm{m}$ range. Since our goal was to elucidate cycling of mercury, the total amount of mercury in the aerosol phase must be determined. We replaced the elutriator in both model 1130 units with one that contained no impaction plate to facilitate collection of coarse aerosols on the quartz frit in the Tekran 1135. The face velocity through the quartz frit was $\sim 3.2 \mathrm{~L} \mathrm{~cm}^{-2} \mathrm{~min}^{-1}$, a much higher rate than through the filters at $\sim 1.1 \mathrm{~L} \mathrm{~cm}^{-2} \mathrm{~min}^{-1}$. At a flow rate of 10 standard liters per minute through the RGM denuder it is highly likely that some of the coarse aerosols will still be lost. However, without completely modifying the instrument this is the best that one can do, and our goal was to evaluate the Tekran system in a likely configuration to be used by researchers.

To help evaluate the accuracy of the Tekran $\mathrm{Hg}^{\mathrm{P}}$ measurements, $\mathrm{Hg}^{\mathrm{P}}$ was also determined using collection of bulk aerosols on Teflon filters. The filter was held upside down in a delrin housing and was situated $\sim 50 \mathrm{~cm}$ away from the inlet of the Tekran unit. We used Millipore fluoropore filters of $90 \mathrm{~mm}$ diameter and a pore size of $1 \mu \mathrm{m}$. The flow meters were calibrated just prior to the campaigns and they were within $\pm 2 \%$ at the flow rates used in this study. Prior to sampling these were cleaned in 12 hour acid soaks of $30 \% \mathrm{HNO}_{3}$ and $25 \% \mathrm{HCl}$. For sampling the filters were placed in custom delrin holders and ambient air flowed through them at $\sim 120$ standard liters per minute. The holders were washed with soapy deionized water and then soaked 12 hours in 5\% $\mathrm{HCl}$. Blank filters went through the same handling process in-between each actual ambient sample. Samples and blanks were stored in clean room bags. Extracts were stored Teflon bottles that were soaked 12 hours in $50 \% \mathrm{HNO}_{3}$, another 12 hours in $30 \% \mathrm{HCl}$, and finally soaked for 5 days in $5 \% \mathrm{HCl}$. Filter extractions were conducted using $1.5 \% \mathrm{BrCl}$ and $\mathrm{HCl}$ for 24 hours. They were then diluted to $0.5 \% \mathrm{BrCl}$ and $\mathrm{HCL}$ for analysis. The average blank filter contained $25 \mathrm{pg}$ of $\mathrm{Hg}$, while the samples contained up to 100 times more $\mathrm{Hg}$. Thus, the blank corrections were essentially in the background noise and contributed little to the overall uncertainty of the ambient measurements.

Analysis of these samples for $\mathrm{Hg}$ was via acid extraction and cold vapor atomic fluorescence using a Tekran Series 2600 System. Calibration standards were prepared from a $1000 \mathrm{ppm} \mathrm{Hg}^{0}$ in $3 \% \mathrm{HNO}_{3}$ Atomic Absorption solution purchased from Ricca Chemical Company. A certified reference material, ORMS-4 (Hg in water), purchased from the National Research Council Canada was utilized as an external standard. The analytical precision of repeated determinations of the ambient samples was $5-10 \%$.

Ozone was measured at each site using UV photometric detection at $254 \mathrm{~nm}$ with a Thermo Environmental Instruments model 49C-PS. The limit of detection was $\sim 1.0$ ppbv. Instrument zeroing and calibration was achieved routinely by utilizing zero air and an internal primary $\mathrm{O}_{3}$ source, respectively. Carbon monoxide was measured with an extensively modified Thermo Environmental Instruments model 48CTL. The technique uses a filter correlation method based on absorption of infrared radiation at $4.6 \mu \mathrm{m}$. Calibration was conducted using standard addition on ambient air from a 
CO primary standard of $\sim 5$ ppmv obtained from Scott Marrin, Inc. (NIST traceable $\pm 2 \%$ ). The addition was dynamically diluted to provide a spike of $\sim 300 \mathrm{ppbv}$. Calibration was performed every 6.25 hours. The limit of detection was $\sim 20$ ppbv. More details of these measurement techniques are presented in Mao and Talbot [36].

A condensation nuclei counter was utilized to measure aerosol number density. The unit was a TSI model 3022A, which was modified to automatically drain and refill the butanol reservoir to remove daily water contamination. The data were averaged to one minute and correspond to individual aerosol particles with a size range of 7 nanometer (nm) to $3 \mu \mathrm{m}$ with an efficiency of $50 \%$ between $7 \mathrm{~nm}$ and $15 \mathrm{~nm}$ and greater than $90 \%$ above $15 \mathrm{~nm}$. The instrument counts aerosol particles up to concentrations of $1 \times 10^{7} \mathrm{~cm}^{-3}$ using standard optical methods. Black carbon was measured using a Magee Scientific aethalometer with light attenuation at $880 \mathrm{~nm}$. More details of these aerosol measurements can be found in Ziemba et al. [37].

For the HCN measurements at Thompson Farm, a cryogen-free concentration system coupled to gas chromatograph (GC) equipped with a flame thermionic detector (FTD) was employed. The system was designed for dual stage trapping such that there were two individual dewars containing cold regions - the first cold region was for water management, while the second cold region was used for sample enrichment. Ambient air was drawn from the main sampling manifold using a single-head metal bellows pump and directed to the concentration system. A $250 \mathrm{~cm}^{3}$ aliquot of air was first dried by passing it through an empty $20 \mathrm{~cm} \times 0.3175 \mathrm{~cm}$ i.d. Silonite-coated loop held at $-15{ }^{\circ} \mathrm{C}$ and then concentrated at $-130{ }^{\circ} \mathrm{C}$ in a $20 \mathrm{~cm} \times 0.3175 \mathrm{~cm}$ i.d. Silonite-coated loop packed with $1 \mathrm{~mm}$ diameter glass beads. After sample enrichment, the loops were heated to $80{ }^{\circ} \mathrm{C}$ and the sample was injected onto a $25 \mathrm{~m} \times 0.32 \mathrm{~mm}$ i.d., $5 \mu \mathrm{m}$ film thickness CP PoraBOND Q column using an 8-port switching valve with ultra high purity (UHP) He. A Shimadzu FTD was used for detection; the chromatographic column and FTD were housed in a Shimadzu 2014 GC. The FTD was operated at $200{ }^{\circ} \mathrm{C}$ using a constant voltage of $80 \%$ relative to maximum. A permeation tube source was used for $\mathrm{HCN}$ calibrations; it was contained in a temperature-regulated glass chamber and had a NIST traceable gravimetric emission rate of $122 \pm 5 \mathrm{ng} \mathrm{min}^{-1}$. The ambient mixing ratios $(\sim 0.1-1 \mathrm{ppbv})$ for the calibrations, the HCN source was first diluted in UHP $\mathrm{N}_{2}$ and then further diluted in zero air using a catalytic converter-zero air generator. The cycle time of the system (from injection to injection) was $\sim 20$ minutes and the $\mathrm{HCN}$ measurement precision was 5\%. Further details regarding operation of the cryogen-free system are in Sive et al. [38].

A high-sensitivity proton transfer reaction-mass spectrometer (PTR-MS) was used for measurements of selected VOCs, OVOCs, dimethylsulfide and acetonitrile at Thompson Farm [39-42]. Briefly, the ion source was operated with a water flow rate of $11 \mathrm{~cm}^{3} \mathrm{~min}^{-1}$, a discharge current of $8 \mathrm{~mA}$ at $600 \mathrm{~V}$, and tuned such that $\mathrm{O}_{2}{ }^{+}$was always less than $1.0 \%$ of the primary ion $\left(\mathrm{H}_{3} \mathrm{O}^{+}\right)$signal (the typical $\mathrm{H}_{3} \mathrm{O}^{+}$signal was $3-5 \times 10^{6} \mathrm{~Hz}$ ). The PTR-MS drift tube operational parameters were set to $600 \mathrm{~V}, 45^{\circ} \mathrm{C}$, and a pressure of 2 mbar; the resulting field strength was 132 Townsend. The quadrupole mass spectrometer was operated in single ion mode, monitoring 47 discrete $\mathrm{m} / \mathrm{z}$ channels corresponding to the compounds of interest. The dwell times for each mass ranged from 10-20 seconds, yielding a cycle time of 7.25 minutes. The system was zeroed every 24 hours for 72 minutes by diverting the ambient air through a heated catalytic converter $(0.5 \% \mathrm{Pd}$ on alumina at $600{ }^{\circ} \mathrm{C}$ ) to establish the instrumental background signal. Following the 72 minute zeroing period, a 
multi-component synthetic standard was automatically introduced into the zero air flow stream for 30 minutes, providing an on-line calibration. The flow of the standard was cycled through three different set points in order to achieve a three-point calibration every three consecutive days. For each calibration event, a single set point was used for the entire 30 minute period. Thus, after three consecutive zero/calibration occurrences, a three-point calibration curve was obtained and the cycle was repeated. The resulting 25.7 hour cycle ensured that the zero frequency did not introduce a temporal bias into the PTR-MS data stream. Furthermore, the online calibration system provided a metric of instrument response on a daily basis, and was performed in conjunction with thorough offline calibrations using our primary standards and a standard dilution system. Mixing ratios for each gas were determined by using the normalized counts per second, obtained by subtracting out the non-zero background signal for each compound, and the calibration factors generated from the primary and secondary standards.

For VOC measurements at Thompson Farm (5 April-25 April 2010), an in situ GC system similar to that described in Sive et al. [38] was used; here we describe the differences with the current VOC system and its operational procedure. The third generation of our automated, cryogen-free GC system was deployed at Thompson Farm in April 2010. The new system utilizes a Stirling (pulse-type) cryocooler (Q-drive) for concentration of air samples without the use of liquid nitrogen or solid absorbents. Moreover, this system is capable of cooling to liquid nitrogen temperatures rapidly ( $\sim 15 \mathrm{~min})$ while providing superior cooling power $(\sim 8 \mathrm{~W}$ at $77 \mathrm{~K})$ to our previous cryogen-free systems at these temperatures. Because of the Qdrive's cooling capacity at liquid nitrogen temperatures, dual-stage trapping for water management was not necessary. For sample concentration, a $6.35 \mathrm{~cm} \times 4.765 \mathrm{~mm}$ i.d. stainless steel loop filled with $1 \mathrm{~mm}$ diameter glass beads was used; the larger diameter $(4.7625 \mathrm{~mm}$ i.d. vs. $3.175 \mathrm{~mm}$ i.d.) sample loop minimized the potential for ice blockage associated with high humidity episodes.

The cryogen free concentrator system was coupled to a Shimadzu GC-17A equipped with two FIDs and two ECDs for measurements of $\mathrm{C}_{2}-\mathrm{C}_{10}$ NMHCs, $\mathrm{C}_{1}-\mathrm{C}_{2}$ halocarbons, $\mathrm{C}_{1}-\mathrm{C}_{5}$ alkyl nitrates and organic sulfur compounds. A $1500 \mathrm{~cm}^{3}$ sample aliquot was trapped at $-196{ }^{\circ} \mathrm{C}$ with the Qdrive cryocooler sample concentrator. After the sample aliquot was concentrated, it was isolated, rapidly heated to $100{ }^{\circ} \mathrm{C}$ and injected. After injection, the sample aliquot was quantitatively split in to four sub-streams, each feeding a separate column-detector pair. A Shimadzu GC-17A housed four different separation columns which were coupled to the FIDs and ECDs. For calibrations, two different whole air standards were analyzed alternately every tenth run in a manner that was identical to the ambient sampling. The measurement precision for each of the NMHCs, halocarbons, alkyl nitrates and sulfur gases ranged from $0.3-15 \%$.

For VOC measurements at Appledore Island, canister samples were collected on an hourly basis from July 26 to August 4, 2009. Air samples were drawn from the top of a $20 \mathrm{~m}$ tall World War II-era coastal surveillance tower and pressurized to 35 psig using a single head metal bellows pump. Samples were returned to the UNH laboratory and were analyzed within two weeks of collection on a three GC system equipped with two flame ionization detectors (FID), two electron capture detectors (ECD), and a mass spectrometer (MS) for the following suite of gases: $\mathrm{C}_{2}-\mathrm{C}_{10}$ nonmethane hydrocarbons (NMHCs), $\mathrm{C}_{1}-\mathrm{C}_{2}$ halocarbons, $\mathrm{C}_{1}-\mathrm{C}_{5}$ alkyl nitrates, select oxygenated volatile organic compounds (OVOCs) and organic sulfur compounds. The measurement precision was $<1-4 \%$ for the $\mathrm{C}_{2}-\mathrm{C}_{8}$ 
NMHCs and 5\% for $\mathrm{C}_{2} \mathrm{Cl}_{4}$ at 6.0 pptv. Specific details regarding measurement precision and calibrations have been described elsewhere $[24,32,38,43,44]$.

\section{Conclusions}

A seasonal study was conducted to ascertain cycling of speciated atmospheric mercury in the marine and continental atmospheric boundary layers. A component of this work focused on assessing the automated Tekran system for measuring $\mathrm{Hg}^{\mathrm{P}}$. Our results suggest that the filter-based $\mathrm{Hg}^{\mathrm{P}}$ has minimal positive artifact from uptake of RGM during sampling. In coastal New Hampshire, where RGM is at its highest mixing ratios in springtime, periodic artifact from RGM uptake could occur. However, comparison of the Tekran and filter $\mathrm{Hg}^{\mathrm{P}}$ values during a period of elevated RGM showed no difference in the measured mixing ratios suggesting that the artifact is essentially immeasurable. The largest discrepancy in measured mixing ratios of filter and Tekran $\mathrm{Hg}^{\mathrm{P}}$ always were associated with the highest levels of filter $\mathrm{Hg}^{\mathrm{P}}$. Peaks in filter $\mathrm{Hg}^{\mathrm{P}}$ occurred in all seasons, and there was corresponding enhancements in selected hydrocarbons, halocarbons, and oxygenated compounds. Most of these cases also had enrichments in $\mathrm{HCN}$ and $\mathrm{CH}_{3} \mathrm{CN}$, indicative of a biomass burning contribution. Since there were no reported wildfires in the backward trajectory determined source regions, we concluded that in winter this must include contributions from regional wood stove and fireplace emissions. In other seasons a variety of anthropogenic sources may be involved, including vehicle emissions, coal combustion, and other combustion types. Almost every peak in filter $\mathrm{Hg}^{\mathrm{P}}$ showed a potential biomass contribution as indicated by tracer compounds. In comparison, the Tekran exhibited little response to these events. Furthermore, we find no consistent disparity in the two methods caused by aerosol size distribution factors. In summer and winter the Tekran yielded somewhat lower correlation with the filter measurements. In springtime they tracked each other much more closely, with the Tekran still providing lower mixing ratios. We conclude that until the discrepancies are understood better between the filter and Tekran methodologies, the filter-based $\mathrm{Hg}^{\mathrm{P}}$ should provide higher values of $\mathrm{Hg}^{\mathrm{P}}$ for research application in chemical cycling studies.

\section{Acknowledgements}

We appreciate the logistical support provided by the Shoals Marine Laboratory on Appledore Island. Financial support was obtained from the National Science Foundation under grant \#ATM0837833, the National Oceanic and Atmospheric Administration AIRMAP program under grant \#NA07OAR4600514, and the Environmental Protection Agency under contract \#EP09H000355.

\section{References}

1. Xiu, G.; Cai, J.; Zhang, W.; Hang, D.; Büeler, A.; Lee, S.; Shen, Y.; Xu, L.; Huang, X.; Zhang, P. Speciated mercury in size-fractionated particles in Shanghai ambient air. Atmos. Environ. 2009, 43, 3145-3154.

2. Mason, R.P.; Sheu, G.R. Role of the ocean in the global mercury cycle. Global Biogeochem. Cycles 2002, 16, doi:10.1029/2001GB001440. 
3. Poissant, L.; Pilote, M.; Beauvais, C.; Constant, P.; Zhang, H.H. A year of continuous measurements of three atmospheric mercury species (GEM, RGM, and $\mathrm{Hg}_{\mathrm{P}}$ ) in southern Quebec, Canada. Atmos. Environ. 2005, 39, 1275-1287.

4. Yatavelli, R.L.N.; Fahrni, J. K.; Kim, M.; Crist, K.C.; Vickers, C.D.; Winter, S.E.; Connell, D.P. Mercury, $\mathrm{PM}_{2.5}$ and gaseous co-pollutants in the Ohio River Valley region: Preliminary results from the Athens supersite. Atmos. Environ. 2006, 40, 6650-6665.

5. Peterson, C.; Gustin, M.; Lyman, S. Atmospheric mercury concentrations and speciation measured from 2004 to 2007 in Reno, Nevada, USA. Atmos. Environ. 2009, 43, 4646-4654.

6. Landis, M.S.; Stevens, R.K.; Schaedlich, F.; Prestbo, E.M. Development and characterization of an annular denuder methodology for the measurement of divalent inorganic reactive gaseous mercury in ambient air. Environ. Sci. Technol. 2002, 36, 3000-3009.

7. Malcolm, E.G.; Keeler, G.J. Evidence for a sampling artifact for particulate-phase mercury in the marine atmosphere. Atmos. Environ. 2007, 41, 3352-3359.

8. Rutter, A.P.; Schauer, J.J. The effect of temperature on the gas-particle partitioning of reactive mercury in atmospheric aerosols. Atmos. Environ. 2007, 41, 8647-8657.

9. Ebinghaus, R.; Jennings, S.G.; Schroeder, W.H.; Berg, T.; Donaghy, T.; Guentzel, J.; Kenny, C.; Kock, H.H.; Kvietkus, K.; Landing, W.; Mühleck, T.; Munthe, J.; Prestbo, E.M.; Schneeberger, D.; Slemr, F.; Sommar, J.; Urba, A.; Wallschläger, D.; Xiao, Z. International field intercomparison measurements of atmospheric mercury species at Mace head, Ireland. Atmos. Environ. 1999, 33, 3063-3073.

10. Poissant, L.; Pilote, M.; Beauvais, C.; Constant, P.; Zhang, H.H. A year of continuous measurements of three atmospheric mercury species (GEM, RGM, and $\mathrm{Hg}^{\mathrm{P}}$ ) in southern Québec, Canada. Atmos. Environ. 2005, 39, 1275-1287.

11. Lyman, S.N.; Gustin, M.S. Speciation of atmospheric mercury at two sites in northern Nevada, USA. Atmos. Environ. 2008, 42, 927-939.

12. Yatavelli, R.L.N.; Fahrni, J.K.; Kim, M.; Crist, K.C.; Vickers, C.D.; Winter, S.E.; Connell, D.P. Mercury, $\mathrm{PM}_{2.5}$ and gaseous co-pollutants in the Ohio River Valley region: Preliminary results from the Athens supersite. Atmos. Environ. 2006, 40, 6650-6665.

13. Xiu, G.; Cai, J.; Zhang, W.; Zhang, D.; Bueler, A.; Lee, S.; Shen, Y.; Xu, L.; Huang, X.; Zhang, P. Speciated mercury in size-fractionated particles in Shanghai ambient air. Atmos. Environ. 2009, $43,3145-3154$.

14. Chand, D.; Jaffe, D.; Prestbo, E.; Swartzendruber, P.C.; Hafner, W.; Weiss-Penzias, P.; Kato, S.; Takami, A.; Hatakeyama, S.; Kajii, Y. Reactive and particulate mercury in the Asian marine boundary layer. Atmos. Environ. 2008, 42, 7988-7996.

15. Lamborg, C.H.; Rolfhus, K.R.; Fitzgerald, W.F. The atmospheric cycling and air-sea exchange of mercury species in the south and equatorial Atlantic Ocean. Deep Sea Res. 1999, 46, 957-977.

16. Mason, R.P.; Fitzgerald, W.F.; Morel, F.M.M. The sources and composition of mercury in Pacific Ocean rain. J. Atmos. Chem. 1992, 14, 489-500.

17. Seigneur, C.; Wrobel, J.; Constantinou, E.A. A chemical kinetic mechanism for atmospheric inorganic mercury. Environ. Sci. Technol. 1994, 28, 1589-1597. 
18. Hedgecock, I.M.; Pirrone, N. Mercury and photochemistry in the marine boundary layer-modeling studies suggest in situ production of reactive gas phase mercury. Atmos. Environ. 2001, 35, 3035-3062.

19. Bullock, O.R. Modeling assessment of transport and deposition patterns of anthropogenic mercury air emissions in the United States and Canada. Sci. Total Environ. 2000, 259, 145-157.

20. Mao, H.; Talbot, R.; Sigler, J.M.; Sive, B.C.; Hegarty, J.D. Seasonal and diurnal variations of $\mathrm{Hg}^{0}$ over New England. Atmos. Chem. Phys. 2008, 8, 1403-1421.

21. Sigler, J.M.; Mao, H.; Sive, B.; Talbot, R. Gaseous elemental and reactive mercury in southern New Hampshire. Atmos. Chem. Phys. 2008, 9, 1929-1942.

22. Feddersen, D.; Talbot, R.; Mao, H.; Smith, M.; Sive, B. Size distribution of atmospheric mercury in marine and continental atmospheres. Atmosphere 2011, to be submitted.

23. Lynam, M.M.; Keeler, G.J. Artifacts associated with the measurement of particulate mercury in an urban environment: The influence of elevated ozone concentrations. Atmos. Environ. 2005, 39, 3081-3088.

24. Blake, D.R.; Chen, T.-Y.; Smith, T.W., Jr.; Wang, J.-L.; Wingenter, O.W. Three dimensional distribution of NMHCs and halocarbons over the northwestern Pacific during the 1991 Pacific Exploratory Mission (PEM-West A). J. Geophys. Res. 1996, 101, 1763-1778.

25. Talbot, R.W.; Beecher, K.M.; Harriss, R.C.; Cofer, W.R. Atmospheric geochemistry of formic and acetic acids at a mid-latitude temperate site. J. Geophys. Res. 1988, 93, 1638-1652.

26. Russo, R.; Zhou, Y.; White, M.L.; Mao, H.; Talbot, R.; Sive, B.C. Multi-year (2004-2008) record of nonmethane hydrocarbons and halocarbons in New England: Seasonal variations and regional sources. Atmos. Chem. Phys. Discuss. 2010, 10, 1083-1134.

27. Munger, J.W.; Fan, S.-M; Bakwin, P.S.; Goulden, M.L.; Goldstein, A.H.; Colman, A.S.; Wofsy, S.C. Regional budgets for nitrogen oxides from continental sources: Variations of rates for oxidation and deposition with season and distance from source regions. J. Geophys. Res. 1998, 103, 8355-8368.

28. Talbot, R.; Mao, H.; Sive B. Diurnal characteristics of surface level O3 and other important trace gases in New England. J. Geophys. Res. 2005, 110, D09307.

29. Mao, H.; Talbot, R.W.; Hegarty, J.D. Long-term variation in speciated mercury at marine, coastal and inland sites in New England. Atmosphere 2011, to be submitted.

30. Kim, S.Y.; Talbot, R.W.; Mao, H. Cycling of gaseous elemental mercury: Importance of water vapor, Geophys. Res. Lett. 2011, to be submitted.

31. Zhou, Y.; Varner, R.K.; Russo, R.S.; Wingenter, O.W.; Haase, K.B.; Talbot, R.W.; Sive, B.C. Coastal water source of short-lived halocarbons in New England. J. Geophys. Res. 2005, 110, doi:10.1029/2004JD005603.

32. Zhou, Y.; Mao, H.; Russo, R.S.; Blake, D.R.; Wingenter, O.W.; Haase, K.B.; Ambrose, J.; Varner, R.K.; Talbot, R.; Sive, B.C. Bromoform and dibromomethane measurements in the seacoast region of New Hampshire, 2002-2004. J. Geophys. Res. 2008, 113, D08305.

33. Chen, M.; Talbot, R.; Mao, H.; Sive, B.; Chen, J.; Griffin, R.J. Air mass classification in coastal New England and its relationship to meteorological conditions. J. Geophys. Res. 2007, 112, doi:10.1029/2006JD007687.

34. Cardno, C.A. Tilting wind turbine tower suits its site. ASCE 2007, 77, 36-37. 
35. Field Standard Operating Procedures for Measurement of Ambient Gaseous and Particulate Mercury, (unpublished); United States Environmental Protection Agency: Washington, DC, USA; National Acid Deposition Program: University of Illinois at Urbana-Champaign, IL, USA; Tekran Instruments: Toronto, Canada, 2007; p.74.

36. Mao, H.; Talbot, R. $\mathrm{O}_{3}$ and $\mathrm{CO}$ in New England: Temporal variations and relationships. J. Geophys. Res. 2004, 109, doi:10.1029/2004JD004913.

37. Ziemba, L.D.; Griffin, R.J.; Talbot, R.W. Observations of elevated particle number concentration events at a rural site in New England. J. Geophys. Res. 2006, 111, D23S34.

38. Sive, B.C.; Zhou, Y.; Troop, D.; Wang, Y.; Little, W.C.; Wingenter, O.W.; Russo, R.S.; Varner, R.K.; Talbot, R. Development of a cryogen-free concentration system for measurements of volatile organic compounds. Anal. Chem. 2005, 77, 6989-6998.

39. Ambrose, J.L.; Mayne, H.R.; Stutz, J.; Russo, R.S.; Zhou, Y.; Varner, R.K.; Nielsen, L.C.; White, M.; Wingenter, O.W.; Haase, K.; Talbot, R.; Sive, B.C. Nighttime oxidation of VOCs at Appledore Island, ME during ICARTT 2004, J. Geophys. Res. 2007, 112, D21302.

40. White, M.; Russo, R.S.; Zhou, Y.; Varner, R.K.; Nielsen, L.C.; Ambrose, J.; Wingenter, O.W.; Haase, K.; Talbot, R.; Sive, B.C. Volatile organic compounds in northern New England marine and continental environments during the ICARTT 2004 campaign, J. Geophys. Res. 2008, 113, D08S90.

41. Jordan, C.; Fitz, E.; Hagan, T.; Sive, B.; Frinak, E.; Haase, K.; Cottrell, L.; Buckley, S.; Talbot, R. Long-term study of VOCs measured with PTR-MS at a rural site in New Hampshire with urban influences, Atmos. Chem. Phys. 2009, 9, 4677-4697.

42. Ambrose, J.L.; Haase, K.; Russo, R.S.; Zhou, Y.; White, M.L.; Frinak, E.K.; Mayne, H.R.; Talbot, R.; Sive, B.C. A comparison of GC-FID and PTR-MS toluene measurements under conditions of enhanced Monoterpenes loading. Atmos. Meas. Tech. 2010, 3, 959-980.

43. Sive, B.C.; Varner, R.K.; Mao, H.; Blake, D.R.; Wingenter, O.W.; Talbot, R. A large terrestrial sources of Methyl Iodide. Geophys. Res. Lett. 2007, 34, L17808.

44. Russo, R.S.; Zhou, Y.; Haase, K.B.; Wingenter, O.W.; Frinak, E.K.; Mao, H.; Talbot, R.W.; Sive, B.C. Temporal variability, sources, and sinks of $\mathrm{C}_{1}-\mathrm{C}_{5}$ alkyl nitrates in Coastal New England, Atmos. Chem. Phys. 2010, 10, 1865-1883.

(C) 2011 by the authors; licensee MDPI, Basel, Switzerland. This article is an open access article distributed under the terms and conditions of the Creative Commons Attribution license (http://creativecommons.org/licenses/by/3.0/). 